\title{
YIELD OF Coffea arabica GRAFTED ONTO Coffea canephora IN SOILS INFESTED WITH NEMATODES IN MEXICO
}

\author{
Francisco Javier López-García ${ }^{1}$, Juan Guillermo Cruz-Castillo²
}

(Received: April 10, 2019; accepted: June 17, 2019)

\begin{abstract}
The total of three consecutive years of fruit production was evaluated in six coffee cultivars (Coffea arabica L.) propagated by seed and grafted onto Robusta (Coffea canephora var. Robusta). The plantations were established at $640 \mathrm{~m}, 920$ $\mathrm{m}$, and $1340 \mathrm{~m}$ altitude in the central region of the Veracruz State, Mexico. The coffea plants were established in soils naturally infested with nematodes. Grafted plants had higher production than those propagated by seed. Fruit production was higher at $640 \mathrm{~m}$ and $920 \mathrm{~m}$ than at $1340 \mathrm{~m}$ for the two types of propagation. The cultivars Colombia Brote Café and Colombia Brote Verde had the highest fruit yield regardless of the propagation methods; in contrast, Pacamara, had the lowest. The grafted coffee plants that were planted at $1340 \mathrm{~m}$ had a yield reduction of $27 \%$ in comparison with those at 640 and $920 \mathrm{~m}$. When the Costa Rica 95 variety was grafted, it achieved fruit yield similar to Colombia Brote Verde and Colombia Brote Café. Pacamara produced almost $28 \%$ more fruit when it was grafted onto Robusta.
\end{abstract}

Index terms: Variety x environment interaction, Robusta, coffee cherry production, Coffea environments.

\section{PRODUÇÃO DE Coffea arabica ENXERTADAS EM Coffea canephora EM SOLOS INFESTADOS COM NEMATÓIDES EM MÉXICO}

\begin{abstract}
RESUMO: O total de três anos consecutivos de produção de frutos foi avaliado em seis cultivares de café (Coffea arabica L.) propagadas por sementes e enxertadas em Robusta (Coffea canephora var. Robusta). As plantações foram estabelecidas a $640 \mathrm{~m}$, 920 m e 1340 m de altitude na região central do estado de Veracruz, no México. As plantas de café foram estabelecidas em solos naturalmente infestados com nematóides. Plantas enxertadas tiveram maior produção do que as propagadas por sementes. A produção de frutos foi maior em $640 \mathrm{~m}$ e $920 \mathrm{~m}$ do que em $1340 \mathrm{~m}$ para os dois tipos de propagação. As cultivares Colombia Brote Café e Colombia Brote Verde apresentaram maior produção de frutos, independentemente dos métodos de propagação. Em contraste, Pacamara, teve o menor. As plantas de café enxertadas que foram plantadas a 1340 m tiveram uma redução de rendimento de 27\% em comparação com aquelas em 640 e 920 m. Quando a variedade Costa Rica 95 foi enxertada, obteve rendimento de frutos semelhante ao da Colômbia Brote Verde e Colômbia Brote Café. A Pacamara produziu quase $28 \%$ mais frutas quando foi enxertada no Robusta.
\end{abstract}

Termos para indexação: Coffea, interação variedade x ambiente, Robusta, produção de café cereja, ambientes para café

\section{INTRODUCTION}

Nematodes are worm-like invertebrate and unsegmented animals that attack coffee plantations around the world and severely reduce fruit production. In Mexico, coffee production has decreased significantly due to nematode infestations in cropland (MARBÁN-MENDOZA, 2009; LÓPEZ-LIMA et al., 2015). Rootstocks have been used to control nematode attack in coffee production fields (ZHANG \& SCHMITT, 1995); they offer environmental advantages over the application of nematicides to the soil (VILLAIN et al., 2000). In Guatemala, hypocotyledonary grafting of the coffee tree has been carried out for more than 45 years (BERTRAND et al., 2001). One of the rootstock species most commonly used to control nematodes is Coffea canephora Pierre var. Robusta (ETIENNE et al., 2002). Most $C$. canephora rootstocks are propagated by seed, and this species is cross-pollinated (ETIENNE et al., 2002). If the rootstocks are not properly selected, they may only have $30-40 \%$ resistance to Meloidogyne incognita (BERTRAND et al., 2000). There are clonal rootstocks of Robusta like the cv. Nemaya (ETIENNE et al., 2002) that tolerate root damage from Meloidogyne and Pratylenchus or the cv. BP 534 (PRAWOTO \& YULIASMARA, 2003) that is drought tolerant. However, commercial coffee production usually uses seedlings because of their low cost (ETIENNE et al., 2002). In Mexico, clonal rootstocks of Robusta are not used commercially, and they have not yet been certified or registered.

Generally, cultivars of Coffea arabica L. grafted on $C$. canephora have greater growth and coffee bean production over time on land with nematode infestation (FAHL et al., 2001, PRAWOTO \& YULIASMARA, 2013). However, when the soil is free of nematodes, there are apparently no advantages to its use. REYES

\footnotetext{
${ }^{1,2}$ Centro Regional Universitario Oriente - Universidad Autónoma Chapingo Km 6.2 Carretera Huatusco - Xalapa - Veracruz 94100 - Mexico - logafja@hotmail.com, jcruzcastillo@yahoo.com
}

Coffee Science, Lavras, v. 14, n. 3, p. 308 - 314, jul./sep. 2019 
et al. (2016) evaluated one season of fruit yield from grafted coffee plants and contrasted them with the same cultivars with their own roots in a highland coffee zone at $1300 \mathrm{~m}$. The seedlings had higher fruit yield than the grafted plants. However, certain scion/rootstock combinations can significantly improve coffee fruit production (PAIVA et al., 2012). The response to the use of Robusta rootstocks in coffee production zones at different altitudes in Mexico is unknown.

Positive effects on coffee fruit production were expected from rootstocks. Thus, the cumulative production over three years from six coffee cultivars propagated by seeds was compared to their production when grafted onto Robusta, in soils infested with nematodes in regions of different altitudes.

\section{MATERIALS AND METHODS}

The experimental material consisted of the Coffea arabica L. cultivars Colombia Brote Verde, Colombia Brote Café, Pacamara, Costa Rica 95, Garnica F5, and Aztec Gold obtained of seed germination as well as grafted onto Coffea canephora Pierre ex Froehner (Robusta coffee). The rootstocks were obtained from seeds of Robusta plants growing in Zentla county at 1000 $\mathrm{m}$ altitude that seemed vigorous and without any disease or insect attack.

Coffee plants were established in Zentla county, Veracruz, Mexico, in the community of Maromilla at $640 \mathrm{~m}$ altitude, with annual averages of rainfall of $1430 \mathrm{~mm}$ and temperature of $22^{\circ} \mathrm{C}$, and in the community of Colonia Manuel González at $920 \mathrm{~m}$ altitude, with annual averages of rainfall of $1604 \mathrm{~mm}$ and temperature of $20^{\circ} \mathrm{C}$. Another plantation was established in Huatusco county, Veracruz, at $1340 \mathrm{~m}$ altitude, with annual averages of rainfall of $1700 \mathrm{~mm}$ and temperature of $17^{\circ} \mathrm{C}$. The plantations were established in September 1998 in lands infested with nematodes. During the experiment, the roots of the coffee plants were found to be infested with nematodes such as Meloidogyne spp., Criconemella spp., Helicotylenchus spp., Tylenchus spp., and Paratylenchus (BARRAGÁN, LÓPEZ \& MARBAN-MENDOZA, 2000; MARBÁNMENDOZA., 2009). These nematode species cause severe damage to Coffea arabica plantations in Veracruz, Mexico (ORISAJO \& FADEMI, 2012).

Planting distance was $2.0 \times 2.5 \mathrm{~m}$ between plants and between rows, respectively. Plots were shaded with trees of the Inga genus in an $8 \times 8 \mathrm{~m}$ frame arrangement, 30 days after the coffee plants were planted. In all the plots in the first year of planting, $50 \mathrm{~g}$ of urea $(46 \mathrm{~N})$ per plant was applied twice, once in March and once in September. In the second year, $100 \mathrm{~g}$ of $18 \mathrm{~N}-46 \mathrm{P}$ was applied in the months indicated. In the third year, two more applications were made at the rate of $200 \mathrm{~g}$ per plant of $18 \mathrm{~N}-46 \mathrm{P}$. Weed control in the plantations was performed manually, and the plants were not pruned throughout the experiment.

The experiment was carried out in a splitsplit plot design (LÓPEZ \& GONZÁLEZ, 2014). The three factors were altitude (Maromilla 640 m, Colonia Manuel González - 920 m, and Huatusco - $1340 \mathrm{~m}$ ), type of plant (grafted and seedling coffee trees), and cultivars (Colombia Brote Verde, Colombia Brote Café, Pacamara, Costa Rica 95, Garnica F5, and Aztec Gold). There were six replications and six plants per experimental unit.

For statistical analysis, the cumulative total of three consecutive years of coffee fruit production (2001-2003) was considered. The fresh fruit weight $\left(\mathrm{kg}\right.$.plant $\left.{ }^{-1}\right)$ was determined in each of the six cultivars of grafted and seedling coffee plants established in the three different environments. Harvest was carried out between December and February in each of the three years. Means were compared by Fisher's LSD method at 5\% (LÓPEZ \& GONZÁLEZ, 2014). The statistical analysis was carried out by the Infostat software (DI RIENZO et al., 2016).

\section{RESULTS AND DISCUSSION}

The altitude, plant type, and variety factors were all significant $(\mathrm{P} \leq 0.05)$ for fruit production. Three interactions were also significant $(\mathrm{P} \leq 0.05)$ : county $\times$ propagation method, environment $\times$ variety, and propagation $\times$ variety.

\section{Altitude}

At altitudes of $640 \mathrm{~m}$ (Maromilla) and $920 \mathrm{~m}$ (Col Manuel González), the coffee trees had greater fruit production than at $1340 \mathrm{~m}$ (Huatusco), irrespective of the type of propagation (Table 1), three years after been established. The lower temperatures in Huatusco may have affected this result. The annual average of Huatusco of $17^{\circ} \mathrm{C}$ was $3^{\circ} \mathrm{C}$ and $5^{\circ} \mathrm{C}$ less than the average annual temperatures reached in Maromilla and Colonia Manuel González, respectively. WAMATU et al. (2003) indicated that variations in fruit production between coffee cultivars with adequate crop practices are mainly influenced by the environment. 
TABLE 1 - Coffee cherry production $\left(\mathrm{Kg}_{\mathrm{pl}} \mathrm{pl}^{-1}\right)$ for all plants over three consecutive years in three different environments: Maromilla (640 m), Col Manuel González (920 m), and Huatusco (1340 m).

\begin{tabular}{cc}
\hline Environment & Total fruit yield $\left({\left.\mathrm{Kg} . p{ }^{-1}\right)}^{-1}\right.$ \\
\hline Maromilla $(640 \mathrm{~m})$ & $6.30 \mathrm{a}^{*}$ \\
Col. M.Glez, $(920 \mathrm{~m})$ & $6.20 \mathrm{a}$ \\
Huatusco $(1340 \mathrm{~m})$ & $4.90 \mathrm{~b}$
\end{tabular}

*Means with the same letters in the column are statistically similar (LSD, 0.05).

In the present study, the highest elevation site had the lowest fruit production. The optimum annual temperature for C. arabica is $18-21^{\circ} \mathrm{C}$, and in regions with an average annual temperature below $17-18^{\circ} \mathrm{C}$, growth is negatively affected (DAMATTA \& COCHICHO, 2006). However, the highland areas where coffee is produced may gain suitability due to climate change (OVALLERIVERO et al., 2015). Therefore, more research and application of technology is necessary for coffee production in these zones.

\section{Type of propagation}

Rootstocks have been used in various horticultural species to increase fruit production (PALLIOTTI et al., 2018). In coffee, rootstocks have mainly been used for nematode control (BERTRAND et al., 2001), drought tolerance (PRAWOTO \& YULIASMARA, 2003), and disease resistance/tolerance (CASTROCAICEDO et al., 2010). In the present study, the grafted coffee trees had higher fruit production in the three different altitudes (Table 2); the difference was nearly $39 \%$. In other studies, increases in production were $89 \%$ and $151 \%$, depending on the coffee scion/rootstock combination (FAHL et al., 2001).

Coffee scion plants grafted onto Robusta showed an increase in the number of stems and an increase of $52 \%$ in total leaf area. In addition, under drought conditions, grafted plants showed higher transpiration and higher stomatal conductance rates than non-grafted plants (FAHL et al., 2001). Then, grafted coffee plants could be an option in dry zones. In some studies, rootstocks negatively affected production of cherry coffee in high altitude areas (REYES et al., 2016), and the lack of adaptation of Robusta to low temperatures may be a determining factor since Robusta rootstocks are more efficient at $20-23^{\circ} \mathrm{C}$. (BERTRAND et al., 2001). The selection of Robusta seeds from highly productive plants in highlands could generate rootstocks that would increase the initial production of $C$. arabica.

In the present study, seedlings and grafted plants initiate fruit yield at the first year of its establishment. Then, trying to avoid possible seedling juvenility effects on fruit production, the recording of the data initiated three years after plants were established.

\section{Cultivars}

Colombia Brote Café and Colombia Brote Verde had the highest cumulative production over three years, regardless of the type of propagation; in contrast, Pacamara had the lowest fruit yield (Table 3). Similar results were reported by LÓPEZ-GARCÍA et al. (2016) in cumulative fruit production over five years for seedling plants established at $800 \mathrm{~m}$ altitude. In that study, the Colombian cultivars Brote Café and Brote Verde were the most productive, and Pacamara was the least. In the coffee plant, a greater load of fruits per plant is associated with smaller grains (Vaast et al., 2006) of low dry weight (Vaast et al., 2005). Thus, Pacamara had the lowest fruit production in the present study, and in other works had the largest grain (LÓPEZ-GARCÍA et al., 2016). Sink-source relationships using rootstocks to improve coffee yield has not been deeply studied.

\section{County $x$ type of propagation interaction}

In each cultivar, the highest production was in grafted plants that were established at $640 \mathrm{~m}$ and $920 \mathrm{~m}$ altitude, and the lowest in seedling plants at the three altitudes in which the plantations were established (Table 4). Across all the cultivars and altitudes, grafted coffees that were planted at 1340 $\mathrm{m}$ had a yield reduction of $27 \%$ in soil infested with nematodes. Thus, selection of rootstocks is necessary for production from grafted coffee trees in highlands. All the seedling plants had a yield reduction of $45 \%$ in relation to the grafted plants established at the 640 and $920 \mathrm{~m}$ altitude. 
TABLE 2 - Fruit production in grafted and seedling plants $\left(\mathrm{Kg}_{\mathrm{p}} \mathrm{pl}^{-1}\right)$ over three consecutive years.

\begin{tabular}{cc}
\hline Propagation & Total fruit yield $\left({\left.\mathrm{Kg} . \mathrm{pl}^{-1}\right)}^{-1}\right.$ \\
Grafting & $7.20 \mathrm{a}^{*}$ \\
Seedling & $4.40 \mathrm{~b}$ \\
\hline *Means with the same letters in the column are statistically similar (LSD, 0.05).
\end{tabular}

TABLE 3 - Coffee fruit production $\left(\mathrm{Kg} . \mathrm{pl}^{-1}\right)$ of six cultivars over three consecutive years.

\begin{tabular}{cc}
\hline Cultivar & Total fruit yield $\left({\left.\mathrm{Kg} . \mathrm{pl}^{-1}\right)}^{-1} \mathrm{a}^{*}\right.$ \\
Colombia BV. & $6.80 \mathrm{a}$ \\
Colombia BC. & $6.00 \mathrm{~b}$ \\
Costa Rica 95 & $5.50 \mathrm{c}$ \\
Garnica & $4.70 \mathrm{~d}$ \\
Pacamara & $4.90 \mathrm{c}$ \\
Oro Azteca
\end{tabular}

*Means with the same letters in the column are statistically similar (LSD, 0.05).

TABLE 4 - Fruit yield of the counties $\times$ type of propagation interaction $\left(\mathrm{Kg}_{\mathrm{pl}} \mathrm{p}^{-1}\right)$.

\begin{tabular}{lcc}
\hline Cultivar & Propagation & Total fruit yield $\left(\mathrm{Kg}_{\mathrm{pl}} \mathrm{l}^{-1}\right)$ \\
\hline Maromilla & Grafting & $7.90 \mathrm{a}$ \\
Colonia Manuel González & Grafting & $8.00 \mathrm{a}$ \\
Huatusco & Grafting & $5.80 \mathrm{~b}$ \\
Maromilla & Seedling & $4.70 \mathrm{bc}$ \\
Colonia Manuel González & Seedling & $4.40 \mathrm{c}$ \\
Huatusco & Seedling & $4.00 \mathrm{c}$ \\
\hline
\end{tabular}

*Means with the same letters in the column are statistically similar (LSD, 0.05).

Nematode damage to the roots influenced this result. In the roots of the seedlings, a large number of nematodes were observed (BARRAGÁN, LÓPEZ \& MARBAN-MENDOZA, 2000; MARBÁN-MENDOZA, 2009). The Robusta rootstocks currently in Mexico are not a solution to low yield and nematode damage in highlands. However, there are individuals of C. canephora that could be adapted to these zones (WEVERTON et al., 2016) can be used as rootstocks. Furthermore, nematode tolerant cultivars of $C$. arabica should be generated for high altitude areas (ANZUETO et al., 2001). In Brazil, 'Acaua', 'Catucai 785/15', 'Elpar 59' (BARBOSA et al., 2010), and progenies of MG 0179-3-R1-151 and MG 0185-2-R2-132 (SANTOS et al., 2018) exhibit individuals of C. arabica that are tolerant to nematodes of the Meloidogyne genus.

\section{Environment $x$ cultivar interaction}

Elevation and cultivar were indicators of coffee yield. The Colombia Brote Café and Colombia Brote Verde cultivars achieved the highest cumulative yields at $920 \mathrm{~m}$ (Colonia Manuel González) (Table 5). However, these two cultivars decreased their yield by $33.5 \%$ when planted at $1340 \mathrm{~m}$.

An absence of the environment $\times$ genotype interaction indicates that the genotypes are very stable (GARCÍA et al., 2015). This is a fact that was not verified in this study. For example, the yield performance of Costa Rica 95 was the same in the three different environments (Table 5). This is the first report in a refereed journal in which the genotype $\times$ environment interaction in the production of cherry coffee in Mexico has been quantified. 
TABLE 5 - Fruit yield $\left(\mathrm{Kg}_{\mathrm{pl}} \mathrm{l}^{-1}\right)$ for the environment $\times$ cultivar interaction.

\begin{tabular}{llc}
\hline Environment & Cultivar & Total fruit yield $\left(\mathrm{Kg}_{\mathrm{pl}} \mathrm{p}^{-1}\right)$ \\
\hline Colonia Manuel González & Colombia BC & $8.7 \mathrm{a}^{*}$ \\
Maromilla & Colombia BV & $6.7 \mathrm{~b}$ \\
Maromilla & Colombia BC & $6.3 \mathrm{bc}$ \\
Colonia Manuel González & Colombia BV & $8.0 \mathrm{ab}$ \\
Maromilla & Costa Rica 95 & $6.5 \mathrm{bc}$ \\
Maromilla & Garnica & $6.2 \mathrm{bc}$ \\
Maromilla & Pacamara & $6.9 \mathrm{~b}$ \\
Maromilla & Oro Azteca & $5.5 \mathrm{bcd}$ \\
Colonia Manuel González & Costa Rica 95 & $5.7 \mathrm{bcd}$ \\
Huatusco & Colombia BV & $5.9 \mathrm{bcd}$ \\
Col. M. Glez & Garnica & $6.0 \mathrm{bcd}$ \\
Huatusco & Costa Rica 95 & $5.9 \mathrm{bcd}$ \\
Colonia Manuel González & Pacamara & $4.3 \mathrm{cde}$ \\
Huatusco & Garnica & $4.5 \mathrm{cde}$ \\
Huatusco & Colombia BC & $5.2 \mathrm{de}$ \\
Huatusco & Oro Azteca & $5.1 \mathrm{de}$ \\
Colonia Manuel González & Oro Azteca & $4.4 \mathrm{cde}$ \\
Huatusco & Pacamara & $2.8 \mathrm{f}$ \\
\hline
\end{tabular}

*Means with the same letters in the column are statistically similar (LSD, 0.05).

TABLE 6 - Type of propagation $\times$ cultivar interaction $\left(\mathrm{Kg}_{\mathrm{p}} \mathrm{pl}^{-1}\right)$.

\begin{tabular}{llc}
\hline Propagation & Cultivar & Total fruit yield \\
\hline Grafting & Colombia BC & $8.70 \mathrm{a}^{*}$ \\
Grafting & Colombia BV & $8.20 \mathrm{a}$ \\
Grafting & Garnica & $7.00 \mathrm{~b}$ \\
Grafting & Costa Rica 95 & $7.70 \mathrm{ab}$ \\
Seedling & Colombia BV & $5.60 \mathrm{c}$ \\
Seedling & Colombia BC & $4.70 \mathrm{~cd}$ \\
Seedling & Costa Rica 95 & $4.50 \mathrm{~cd}$ \\
Grafting & Oro Azteca & $6.00 \mathrm{bc}$ \\
Grafting & Pacamara & $5.40 \mathrm{c}$ \\
Seedling & Pacamara & $3.90 \mathrm{~d}$ \\
Seedling & Garnica & $4.00 \mathrm{~d}$ \\
Seedling & Oro Azteca & $3.90 \mathrm{~d}$
\end{tabular}

*Means with the same letters in the column are statistically similar (LSD, 0.05).

Future studies to manage nematode attack in coffee plantations may consider the use of rootstocks together with cover crops that suppress nematodes (WANG et al., 2002), application of bionematicides (BRAND et al., 2004), and specific nutrition management practices to confer nematode resistance to coffee plants (SANTANA-GOMES et al., 2013). 


\section{Type of propagation $\mathbf{x}$ cultivar interaction}

All the cultivars produced more fruit when they were grafted (Table 6). Colombia Brote Café and Brote Verde had the highest production in the cumulative total of three years. Other studies showed that specific scion/rootstock combinations determine high yield (FAHL et al., 2001), even with a considerable number of nematodes in the soil (ZHANG \& SCHMIDTT, 1995). Cultivars with low yields in the center of Veracruz, such as the Pacamara variety (LÓPEZ-GARCÍA et al., 2016), might have higher yields with the use of adequate rootstocks (ETIENNE et al., 2002; PRAWOTO \& YULIASMARA, 2003); in the present study, Pacamara produced almost 28\% more fruit when it was grafted onto Robusta.

\section{CONCLUSIONS}

The Coffea arabica cultivars studied, both grafted or planted as seedlings in areas with nematodes, had higher production at $640 \mathrm{~m}$ and $920 \mathrm{~m}$ altitude than at $1340 \mathrm{~m}$.

The cultivars Colombia Brote Café, and Colombia Brote Verde grafted on Robusta are recommended for planting on soils naturally infested with nematodes at $920 \mathrm{~m}$ altitude, in the central region of Veracruz.

The Pacamara variety, characterized by larger sized coffee beans and low yield, is recommended for planting in lowland areas since it had better yields at $640 \mathrm{~m}$ than at $940 \mathrm{~m}$ and $1340 \mathrm{~m}$.

This is the first report in a refereed journal where the genotype $\mathrm{x}$ environment interaction has been quantified in the cumulative total of three consecutive years of coffee fruit production in Mexico.

\section{REFERENCES}

ANZUETO, F. et al. Resistance to Meloidogyne incognita in Ethiopian Coffea arabica accessions. Euphytica, v. 118, p. 1-8, 2001.

BARBOSA, D. H. S. G.; SOUZA, R.M.; VIEIRA, H.D. Field assessment of coffee (Coffea arabica L.) cultivars in Meloidogyne exigua-infested or -free fields in Rio de Janeiro State, Brazil. Crop Protection, v. 29, p. 175-177, 2010.

BARRAGÁN, G.,M. LÓPEZ, G.,F.J., MARBAN, M.,N. Evaluación de germoplasma de (Coffea arabica L. $y$ C. canephora) a fitonematodos agalladores lesionadores en Huatusco, Veracruz, México. Resumen XXVII Congreso Nacional de la Sociedad Mexicana de Fitopatología A.C. Puerto Vallarta, Jalisco, México, 2000.
BERTRAND, B.; ETIENNE, H.; ESKES, A. Growth, production, and bean quality of Coffea arabica as affected by interspecific grafting: consequences for rootstock breeding. HortScience, v. 36, n. 2, p. 269273, 2001.

BERTRAND, B. et al. Genetic study of Coffea canephora coffee tree resistance to Meloidogyne incognita nematodes in Guatemala and Meloidogyne sp. nematodes in El Salvador for selection of rootstock varieties in Central America. Euphytica, v. 113, n. 2, p. 79-86, 2000.

BRAND, D. et al. Development of a bionematicide with Paecilomyces lilacinus to Control Meloidogyne incognita, Applied Biochemistry and Biotechnology, v. 118, p. 81-88, 2004.

CASTRO-CAICEDO, B. L.; CORTINA-GUERRERO, H. A.; SÁNCHEZ-ARCINIEGAS, P. M. Evaluación de injertos de café sobre patrones resistentes a Ceratosystis fimbriata Ell. Halts. Hunt. Cenicafé, v. 6, n. 1, p. 46-54, 2010.

DAMATTA, F. M.; COCHICHO, R. J. D. Impacts of drought and temperature stress on coffee physiology and production: a review. Brazilian Journal of Plant Physiology, v. 18, n. 1, p. 55-81, 2006.

DI RIENZO, J. A. et al. InfoStat versión 2016. Grupo InfoStat, FCA, Universidad Nacional de Córdoba, Argentina. 2016

ETIENNE, H. et al. Biotechnological applications for the improvement of coffee (Coffea arabica L.). In Vitro Cell and Developmental Biology-Plant, v. 38, p. 129-138, 2002.

FAHL, J. et al. Gas exchange, growth, yield and beverage quality of Coffea arabica cultivars grafted on to C. canephora and C. congensis. Experimental Agriculture, v. 37, n. 2, p. 241-252, 2001.

GARCÍA, L. J. C.; ELÍAS POSADA S. H. E. H.; ANTONIO SALAZAR, V. F.A. Factores de producción que influyen en la respuesta de genotipos de Coffea arabica L. bajo diversas condiciones ambientales de Colombia. Cenicafé, v. 66. n. 2, p. 30-57, 2015.

LÓPEZ, B. E. A.; GONZÁLEZ, R. B. H. Diseño y análisis de experimentos fundamentos y aplicaciones en agronomía. Universidad de San Carlos de Guatemala Facultad de Agronomía. 240 p., 2014. 
LÓPEZ-GARCÍA, F. J.; ESCAMILLA-PRADO E.; ZAMARRIPA-COLMENERO, A.; CRUZCASTILLO, J. G. Producción y calidad en variedades de café (Coffea arabica L.) en Veracruz, México. Revista de Fitotecnia Mexicana, v. 39, n. 3, p. $297-$ 304, 2016.

LÓPEZ-LIMA, D. et al. Corky-root symptoms for coffee in central Veracruz are linked to the root-knot nematode Meloidogyne paranaensis, a new report for Mexico. European Journal of Plant Pathology, v. 141, n. 3, p. 623-629, 2015.

MARBÁN-MENDOZA, N. Nematodes Management in Coffee Production Systems. In: Ciancio A., Mukerji K. (eds) Integrated Management of Fruit Crops Nematodes. Integrated Management of Plant Pests and Diseases, v. 4. Springer, Dordrecht. 2009.

ORISAJO, S. B.; FADEMI, O. A. Plant-parasitic nematodes associated with coffee in Nigeria. International Journal of Science and Nature, v. 3, n. 4, p. 768-772, 2012.

OVALLE-RIVERA, O. et al. Projected Shifts in Coffea arabica Suitability among Major Global Producing Regions Due to Climate Change. Plos One, v. 10, n. 4, p. e0124155, 2015.

PAIVA, F. R. et al. Comportamento de cultivares de cafeeiros C. Arabica L. enxertados sobre cultivar 'Apoatã IAC 2258' (Coffea canephora). Ciência Rural, v. 42, n 7, p. 1155-1160, 2012.

PALLIOTTI, A.; PONI, S.; SILVESTRONI, O. Manuale di viticoltura. Edagricole. New Business Media. p. 203-224. ISBN 978-88-506-5533-5, 2018.

PRAWOTO, A. A.; YULIASMARA F. Effect of Rootstocks on Growth, Yield and Bean Quality of Coffea canephora Clones. Journal of Agricultural Science and Technology, v. 3, p. 429-438, 2013.

REYES, G. F. et al. Evaluación de productividad, calidad física y sensorial del grano del café (Coffea arabica L.), en cafetos injertados en el CRUO, Huatusco, Veracruz. Revista de Geografía Agrícola, v. 56, p. 45-53, 2016.
SANTANA-GOMES, S. M. et al. Mineral nutrition in the control of nematodes. African Journal of Agricultural Research, v. 8, n. 21, p. 2413-2420, 2013.

SANTOS, H. F. et al. Initial productive performance of coffee progenies in an area infested by Meloidogyne paranaensis. Coffee Science, v. 13, n. 4, p. 530 - 538, 2018.

VAAST, P. et al. Fruit load and branch ring-barking affect carbon allocation and photosynthesis of leaf and fruit of Coffea arabica in the field. Tree Physiology, v. 25, n. 6, p. 753-760, 2005.

VAAST P.et al. Fruit thinning and shade improve bean characteristics and beverage quality of coffee (Coffea arabica L.) under optimal conditions. Journal of the Science of Food and Agriculture, v. 86, n. 2, p. 197 204, 2006.

VILLAIN, L. et al. Effect of grafting and nematicide treatments on damage by root-lesion nematodes (Pratylenchus spp.) to Coffea arabica L. in Guatemala. Nematropica, v. 30, n. 1, p. 87-100, 2000.

WAMATU, J. N.; THOMAS, E.; PIEPHO, H. P. Responses of different arabica coffee (Coffea arabica L.) clones to varied environmental conditions. Euphytica, v. 129, n 2, p. 175-182, 2003.

WANG, K. H.; SIPES, B.S.; SCHMITT, P. Crotalaria as a cover crop for nematode management: A review. Nematropica, v. 32, n 1, p. 35-57, 2002.

WEVERTON, P. R. et al. Physiological aspects, growth and yield of Coffea spp. in areas of high altitude. Australian Journal of Crop Science, v. 10. n. 5, p. 666-674, 2016.

ZHANG, F.; SCHMITT, D. P. Spatial-temporal Patterns of Meloidogyne konaensis on Coffee in Hawaii. Journal of Nematology, v. 27, n. 1, p. 109-113, 1995. 